\title{
STRES DAN KEPUASAN KERJA, DAMPAKNYA TERHADAP KINERJA KAR YAWAN KONTRAK
}

\section{Oleh:}

\author{
M. Fatkhur Rozi*
}

\begin{abstract}
This research examines how stress affect job satisfaction and employees performance. Stress in this research consist of work stress, group stress, financial stress, and family stress, where is fourth variable of stres affect job satisfaction and employees performance either through indirect and also direct. The research using data from a survey of 117 contract employees in Batu police Pamong Praja office use path analysis. The research finding that work stress, financial stress, and family stress affect performance either through direct and also indirectly through job satisfaction. As for group stress not be found to have influence do well by job satisfaction and performance. The research implication to organization studied furthermor.
\end{abstract}

Keyword: Work Stressor, Group Stressor, Financial Stressor, Family Stressor, Job Satisfaction, Performance

\section{PENDAHULUAN}

Dalam setiap organisasi, manusia mempunyai peranan penting baik secara individu maupun kelompok. Sebagai sumber daya dalam organisasi manusia merupakan penggerak utama atas segala aktivitas yang ada. Oleh karena itu perlu diperhatikan baik secara kuantitas maupun kualitasnya. Hal tersebut berkaitan dengan efektifitas pencapaian tujuan yang ingin dicapai dan telah ditetapkan oleh organisasi.

Pencapaian tujuan organisasi dapat dilakukan tanpa hambatan yang berarti dalam setiap aktivitas, jika pembinaan terhadap para karyawan dilakukan sedemikian rupa seperti hubungan antar karyawan, hubungan atasan dan bawahan, 
pemeliharaan lingkungan kerja dan tidak ketinggalan perihal penanganan stres secara dini.

Manajemen sumber daya manusia lebih mengacu pada pengembangan sumber daya manusia daripada manajemen personalia tradisional yang berorientasi pada aspek rutinitas organisasi. Manajemen sumber daya manusia pada dasarnya banyak memberikan dorongan kepada karyawan untuk bekerja produktif, berdayaguna, dan berhasilguna. Produktivitas seorang pekerja bergantung pada tingkat kepuasan kerja yang dinikmatinya dan tingkat stres yang selalu membayanginya (Mangkuprawira, 2002).

Stres yang terjadi pada diri karyawan sebenarnya merupakan keadaan yang wajar yang terbentuk pada diri manusia sebagai respon terhadap suatu hasrat atau kehendak. Akan tetapi apabila hal ini dibiarkan berkelanjutan dan mengarah pada tingkat stres kerja yang tinggi maka nantinya akan berpengaruh negatif pada kinerja karyawan (Anorogo \& Widiyanti 1990:163). Sebagaimana dinyatakan oleh Gitosudarmo dan Sudita (1997:57), bahwa stres mempunyai dampak positif dan negatif. Dampak positif stres kerja pada tingkat rendah sampai moderat bersifat fungsional dalam arti berperan sebagai pendorong peningkatan kinerja karyawan.

Ada berbagai faktor yang menjadi penyebab terjadinya stres pada karyawan yaitu kelebihan beban kerja, pemimpin yang kurang adil, waktu dan peralatan yang kurang memadai, konflik antar pribadi dengan pemimpin atau kelompok kerja, balas jasa yang terlalu rendah, dan masalah keluarga (Malayu, 2000:201). Dalam hal beban kerja Gibson (1996) menyatakan bahwa beban kerja yang dapat 
memberikan dampak negatif bisa dalam bentuk beban kerja yang berlebihan ataupun beban kerja yang kurang.

Berbagai penelitian sering dilakukan terhadap stres terutama stres yang disebabkan oleh pekerjaan (job stress). Indikator yang sering digunakan untuk menggambarkan dari stres pekerjaan ini adalah konflik peran (role conflict) dan kemenduaan peran (role ambiguity). Penelitian yang dilakukan oleh Ruyter, Wetzels, dan Feinberg (2001) menyatakan, bahwa tekanan peran berpengaruh terhadap kepuasan kerja yang selanjutnya mempengaruhi kinerja dan perputaran karyawan. Moncrief, Babakus, dan Johnson (1997) menyatakan bahwa ko mponen tekanan kerja yang kemudian menjadi faktor-faktor penyebab tekanan kerja antara lain adalah konflik peran dan ambiguitas peran.

Tekanan dari kelompok kerja (Group Stressor) dapat menjadi penyebab timbulnya perasaan tertekan pada individu. Hal ini berkaitan dengan bentuk dukungan sosial terhadap individu pada saat melaksanakan pekerjaannya. Hubungan dengan supervisor dan rekan kerja yang diukur oleh dua komponen yaitu tingkat kohesi dan dukungan menjadi faktor penting dalam menciptakan suatu kepuasan kerja (Cheryl Martinez, 2004).

Tekanan keuangan (financial stress) merupakan faktor penyebab stres karyawan diluar organisasi yang dimungkinkan mempengaruhi faktor tekanan organisasi (organizational stressor) secara keseluruhan. Hal ini dikarenakan tekanan keuangan merupakan bentuk tekanan terhadap individu yang berhubungan dengan tingkat kemampuan pendapatan yang diperoleh dalam memenuhi kebutuhan hidupnya. Hal ini berkaitan dengan kompensasi dalam kerja dapat memberikan kepuasan individu sebagaimana kepuasan kerja itu sendiri 
(Bailey, William, Woodiel, Turner \& Young, 1998). Dalam penelitian lainnya menyatakan bahwa karyawan dengan pengalaman stres keuangan pada periode sebelumnya, akan melakukan ketidakhadiran lebih banyak dari yang lain (Um dan Harison, 1998).

Dari segi manajemen, stres kerja berpengaruh terhadap kinerja individu, rendahnya produktivitas, rendahnya kepuasan kerja (Robbins, 1997). Juga membawa dampak terhadap menurunnya kemampuan individu dalam membuat keputusan, meningkatnya angka ketidakhadiran, serta tingginya angka perpindahan (Steers, 1984), dan rendahnya semangat kerja individu.

Penelitian sering dilakukan untuk melihat hubungan dan pengaruh stres terhadap kepuasan kerja, terutama dikaitkan dengan profesi yang berhubungan dengan beban yang berat dalam pelaksanaan tugas. Walaupun stres dapat terjadi pada siapapun termasuk anak-anak, profesi tertentu mendapatkan stres lebih daripada yang lain. Mereka meliputi tenaga penjualan, broker perdagangan saham, sekretaris, guru sekolah yang jauh dari perkotaan, pengatur lalu lintas, tenaga medis rumah sakit, anggota militer, polisi dan ketertiban, serta mereka yang menangani departemen keluhan (Shahid Athar, 2005).

Selanjutnya pada tataran konseptual, Robbins (1997) menjelaskan bahwa kepuasan kerja merupakan sikap umum seseorang terhadap pekerjaannya. Seseorang dengan tingkat kepuasan kerja tinggi akan menunjukkan sikap positif terhadap pekerjaannya, sebaliknya seseorang yang tidak puas akan menunjukkan sikap negatif.

Satuan Polisi Pamong Praja merupakan alat pemerintah yang bertugas menegakkan peraturan daerah yang telah ditetapkan oleh pihak eksekutif dan 
legislatif maupun keputusan walikota sebagai kepala daerah. Tugas pokok dan fungsi dari Polisi Pamong Praja meliputi tugas-tugas pengawasan dan pengandalian, ketentraman dan ketertiban, serta keamanan.

Dilihat dari karakter pekerjaan, personel Satuan Polisi Pamong Praja dituntut untuk bekerja dengan beban kerja yang tinggi. Terhadap status sebagai karyawan kontrak gaji yang diterima lebih kecil dibandingkan dengan karyawan tetap (PNS), sedangkan kebutuhan hidup cenderung tinggi terutama akibat kebijakan pemerintah menaikkan harga BBM.

\section{Rumusan Masalah}

1. Apakah terdapat pengaruh langsung stres terhadap kepuasan kerja karyawan kontrak di lingkungan Kantor Satuan Polisi Pamong Praja Kota Batu?

2. Apakah terdapat pengaruh langsung stres terhadap kinerja karyawan kontrak di lingkungan Kantor Satuan Polisi Pamong Praja Kota Batu?

3. Apakah terdapat pengaruh tidak langsung stres terhadap kinerja karyawan kontrak melalui kepuasan kerja di lingkungan Kantor Satuan Polisi Pamong Praja Kota Batu?

\section{Tujuan Penelitian}

1. Untuk menjelaskan pengaruh langsung stres terhadap kepuasan kerja karyawan kontrak di lingkungan Kantor Satuan Polisi Pamong Praja Kota Batu.

2. Untuk menjelaskan pengaruh langsung stres terhadap kinerja karyawan kontrak di lingkungan Kantor Satuan Polisi Pamong Praja Kota Batu. 
3. Untuk menjelaskan pengaruh tidak langsung stres terhadap kinerja melalui kepuasan kerja karyawan kontrak di lingkungan Kantor Satuan Polisi Pamong Praja Kota Batu.

\section{KERANGKA TEORI}

\section{Pengertian Stres}

Stres adalah tanggapan penyesuaian, diperantai oleh perbedaan-perbedaan individu dan atau proses psikologis yang merupakan suatu konsekuensi dari setiap tindakan dari luar (lingkungan) situasi/peristiwa yang menetapkan permintaan psikologis dan atau fisik berlebihan pada seseeorang (Gibson et al,1996:339).

Sedangkan suatu kajian secara mendalam menyatakan bahwa stres terjadi manakala terdapat ketidakseimbangan atau ketidaksesuaian yang sangat berarti antara persepsi individu terhadap suatu tuntutan yang dihadapinya dan kemampuannya mengatasi tuntutan tersebut (Lazarus dan Folkman, 1986:235).

Tanggapan penyesuaian merupakan respon dari seseorang, oleh karena itu stres adalah respon seseorang yang berupa emosi, fisik dan kognitif (konseptual) terhadap situasi yang meminta tuntutan tertentu pada individu. Dengan demikian stres merupakan dinamika seseorang dari waktu ke waktu, sehingga stres merupakan kondisi dinamis individu yang dikonfrontasikan degan suatu peluang, kendala/tuntutan yang dikaitkan dengan apa yang sangat diinginkan dan yang hasilnya dipersepsikan sebagai sesuatu yang tidak pasti dan penting (Robbins 1997:222). 


\section{Sumber Stres}

Luthans (2002:397) membagi penyebab stres (stressor) dalam beberapa sumber baik dari dalam maupun dari luar organisasi, yaitu extraorganizational stressor, organizational stressor, group stressor, dan individual stressor. Extraorganizational stressor meliputi perubahan sosial/teknologi, globalisasi, keluarga, relokasi, kondisi keuangan dan ekonomi, masalah ras dan kelas, dan kondisi tempat tinggal atau komunitas. Organizational stressor meliputi strategi dan kebijakan administratif, struktur dan desain organisasi, proses-proses organisasi, dan kondisi kerja. Group stressor meliputi dua hal yaitu tidak adanya kohesifitas kelompok, dan tidak adanya dukungan sosial. Individual stressor meliputi pola kepribadian tipe A, pengendalian personal, ketidakmampuan untuk mempelajari sesuatu, dan daya tahan psikologis.

\section{- Tekanan kerja (Job Stress)}

Beehr dan Newman dalam Luthans (2002:396) mendefinisikan tekanan kerja (job stress) sebagai suatu kondisi yang muncul dari interaksi seseorang dengan pekerjaannya dan oleh perubahan dalam diri orang itu sendiri yang akhirnya mendorong mereka berperilaku menyimpang dari fungsi normal mereka.

\section{- Tekanan Kelompok Kerja (Group Stressor)}

Faktor lain yang mempengaruhi tingkat stres di tempat kerja adalah keadaan interaksi yang terjadi di lingkungan kerja baik antar karyawan maupun dengan atasan, begitu juga sebaliknya.. Stres kelompok ini sering disebabkan kepercayaan yang rendah, kohesivitas rendah diantara anggota kelompok, rendahnya dukungan yang dirasa oleh individu, dan norma kelompok yang tidak sesuai (Gibson, 1996). 


\section{- Tekanan Keuangan (Financial Stress)}

Tekanan keuangan merupakan salah satu faktor penting yang saat ini sering dijadikan alasan oleh karyawan yang berhubungan dengan turunnya produktivitas. Masalah keuangan sangat mungkin mempengaruhi tingkat produktivitas kerja individual dan hubungan perseorangan (Williams, Haldeman, Cramer, 1996).

\section{Kepuasan Kerja}

Kepuasan kerja adalah seperangkat perasaan karyawan tentang menyenangkan atau tidak menyenangkannya pekerjaan mereka. Kepuasan kerja menunjukkan kesesuaian antara harapan seseorang yang timbul dan imbalan yang disediakan pekerjaan, jadi kepuasan kerja juga berkaitan erat dengan teori keadilan, perjanjian psikologis dan motivasi. (Davis \& Newstrom, 1985:105).

Kepuasan kerja memiliki banyak dimensi. Ia dapat mewakili sikap secara menyeluruh atau mengacu pada bagian pekerjaan seseorang. Menurut Robbins (1997:192), kepuasan kerja terdiri dari 5 (lima) dimensi antara lain :

1. Pekerjaan itu sendiri.

2. Upah dan Promosi

3. Lingkungan kerja

4. Rekan kerja, penyelia dan atasan.

5. Kesesuaian antara pekerjaan dan kepribadian

\section{Kinerja}

Untuk melihat keberhasilan pelaksanaan kegiatan, kata kinerja sering dipergunakan untuk menggambarkan pencapaian kegiatan yang telah 
direncanakan, hal ini merujuk pendapat yang dikemukakan oleh Sutherland (1987:628) bahwa kinerja lebih dapat mencerminkan kriteria yang tepat dari keberhasilan suatu organisasi publik dalam mencapai sasaran yang telah ditetapkan, lebih lanjut dinyatakan bahwa "effectiveness refers to degree to which the organization performs its intended mission" oleh karenanya efektivitas harus benar-benar memperhatikan pencapaian sasaran/misi yang diemban oleh organisasi yang bersangkutan. Demikian pula Etzioni (1982:12) mengatakan bahwa "kinerja organisasi diukur dari tingkat sejauh mana ia mencapai tujuan".

Kinerja dipengaruhi oleh motif-motif individu, sebagaimana dikemukakan oleh Steers dan Porte (1987:30) bahwa kinerja (performance) dipengaruhi oleh motif-motif individu dalam berinteraksi dengan lingkungan. Dalam mengendalikan kinerja, Drucker (1977: 237-245) mengemukakan bahwa kinerja mempunyai lima dimensi, yaitu :

1. Dimensi Fisiologis, manusia akan bekerja dengan baik apabila bekerja dalam berbagai konfigurasi operasional, yakni bekerja dengan berbagai ragam tugastugas dan ritme kecepatan yang sesuai dengan fisiknya.

2. Dimensi Psikologis, bekerja merupakan ungkapan kepribadian. seseorang yang memperoleh kepuasan dari pekerjaannya akan menampilkan kinerja yang lebih baik daripada mereka yang tidak menyenangi pekerjaannya.

3. Dimensi Sosial, bekerja dapat dipandang sebagai suatu ungkapan hubungan sosial diantara sesama pegawai. Situasi yang menyebabkan perpecahan antar pegawai, dapat menurunkan kinerja baik secara individual maupun kelompok.

4. Dimensi Ekonomi, bekerja adalah kehidupan bagi pegawai, imbalan jasa yang tidak sepadan dapat menghambat atau memacu pegawai untuk berprestasi. 
5. Dimensi Keseimbangan, dalam hubungan ini, keseimbangan antara apa yang diperoleh dari pekerjaan dengan kebutuhan hidup akan memacu seseorang untuk berusaha lebih giat guna mencapai keseimbangan atau sebaliknya.

\section{METODE PENELITIAN}

\section{Desain Penelitian}

Desain penelitian yang digunakan pada penelitian ini adalah penelitian survey.. Lebih lanjut apabila ditinjau dari tujuannya, penelitian ini merupakan penelitian penjelasan (Explanatory Research) yaitu menyoroti hubungan antara variabel-varaibel penelitian. Unit analisis dalam penelitian ini adalah individu yang merupakan karyawan dengan status kontrak. Responden yang digunakan meliputi seluruh karyawan dengan status tenaga kontrak yang berada di lingkungan Kantor Satuan Polisi Pamong Praja Kota Batu.

\section{Tempat dan Waktu Penelitian}

Penelitian ini dilakukan di Kantor Satuan Polisi Pamong Praja Kota Batu Jawa Timur, Penelitian ini dilaksanakan pada bulan Desember 2005 sampai dengan bulan Januari 2006.

\section{Populasi dan Sample Penelitian}

Dalam penelitian ini populasi juga dijadikan sampel penelitian. Yang menjadi satuan penelitian yang juga merupakan populasi penelitian adalah seluruh pegawai/tenaga kontrak Kantor Satuan Polisi Pamong Praja Kota Batu yang berjumlah 117 orang. 


\section{Teknik Pengumpulan dan Analisis Data}

Dalam penelitian ini menggunakan 2 sumber data, yaitu data primer dan data sekunder. Dalam penelitian ini analisis data yang digunakan adalah analisis statistik deskriptif dan analisis statistik inferensial yaitu analisis jalur (Path Analysis).

\section{Pengujian Hipotessis}

- $\mathrm{H}_{0}$ : tidak terdapat pengaruh antara variabel bebas terhadap variabel tergantung

- $\mathrm{H}_{1}$ : terdapat pengaruh antara variabel bebas terhadap variabel tergantung

Adapun dasar pengambilan keputusannya adalah:

- $\mathrm{P}<0,05$ maka H0 ditolak, H1 diterima

- $\mathrm{P}>$ 0,05 maka H0 diterima, H1 ditolak

\section{Hasil Penelitian}

Pengujian hipotesis ini dilakukan dengan teknik analisis statistik regresi sederhana yang distandarisasi dengan menggunakan analisis jalur (path analysis),dari hasil olahan komputer sub program SPSS for Windows.

Hipotesis 1: Ada pengaruh langsung yang signifikan stres pekerjaan, stres kelompok kerja, stres keuangan, dan stres keluarga terhadap kepuasan kerja

\section{a. Pengaruh stres pekerjaan te rhadap kepuasan kerja}

Terdapat bentuk hubungan yang negatif antara stres pekerjaan dengan kepuasan kerja. Bagi karyawan Satuan Polisi Pamong Praja dengan status tenaga kontrak, konflik peran yang dirasa, kemenduaan peran, dan beban kerja yang berat merupakan hal yang dapat menurunkan kepuasan kerja. Hal ini dapat dibuktikan 
dengan nilai t hitung 2,213 yang lebih besar dari t tabel 1,980 dengan nilai probabilitasnya yang lebih kecil dari 0,05 yaitu 0,036. Hasil ini menunjukkan pengaruh yang signifikan antara variabel stres pekerjaan terhadap kepuasan kerja.

Hasil penelitian ini mendukung terhadap penelitian Myung-Yong dan Dianne (1998) yang menyatakan terdapat pengaruh langsung konflik peran dan kemenduaan peran terhadap kepuasan kerja. Penelitian ini juga mendukung terhadap penelitian yang dilakukan oleh Ruyter, Wetzels, dan Feinberg (2001) yang menyatakan tekanan peran berpengaruh terhadap kepuasan kerja yang selanjutnya mempengaruhi kinerja individu.

\section{b. Pengaruh stres kelompok kerja terhadap kepuasan kerja}

Hasil penelitian ini menunjukkan terjadinya hubungan yang negatif stres kelompok kerja yang tidak signifikan terhadap kepuasan kerja dan sejalan dengan hal tersebut tidak ditemukan pengaruh langsung yang signifikan variabel stres kelompok kerja terhadap kepuasan kerja. Hal ini dibuktikan dengan nilai t hitung sebesar 1,908 yang lebih kecil dari nilai t tabel sebesar 1,980 dengan nilai probabilitasnya yang lebih besar dari 0,05 yaitu 0,059 .

Hasil penelitian ini mendukung terhadap penelitian yang dilakukan oleh Paula Brough dan Judi Pears (2002), yang menyatakan bahwa kohesivitas dan dukungan rekan kerja tidak secara signifikan berpengaruh terhadap kepuasan kerja. Hasil penelitian ini tidak mendukung kepada hasil temuan yang dilakukan Myung-Yong dan Dianne (1998) yang menyatakan bahwa dukungan sosial tempat kerja berpengaruh terhadap kepuasan kerja. 


\section{c. Pengaruh stres keuangan terhadap kepuasan kerja}

Hasil penelitian ini menunjukkan terjadinya hubungan yang negatif stres keuangan yang signifikan terhadap kepuasan kerja dan sejalan dengan hal tersebut ditemukan pengaruh langsung yang signifikan variabel stres keuangan terhadap kepuasan kerja. Hal ini dibuktikan dengan nilai t hitung sebesar 4,287 yang lebih besar dari nilai t tabel sebesar 1,980 dengan nilai probabilitasnya yang lebih kecil dari 0,05 yaitu 0,00 .

Hasil penelitian ini mendukung terhadap penelitian yang dilakukan oleh. Bailey, Woodiel, Turner, dan Young (1998) yang menyatakan bahwa terdapat hubungan yang signifikan antara stres keuangan yang diukur dengan manfaat, upah, dan kondisi keuangan terhadap kepuasan secara keseluruhan.

\section{d. Pengaruh stres keluarga te rhadap kepuasan kerja}

Hasil penelitian ini menunjukkan terdapat pengaruh yang signifikan variabel stres keluarga terhadap kepuasan kerja dengan bentuk hubungan yang negatif. Hal in dibuktikan dengan nilai t hitung sebesar 2,221 yang lebih besar dari nilai t tabel sebesar 1,980 dengan nilai probabilitasnya lebih kecil dari 0,05 yaitu 0,029.

Hasil penelitian ini sejalan dengan penilitian yang dilakukan oleh Cole, Ibrahim, Shannon, Scott, dan Eyles (2002) yang menyatakan bahwa kejadiankejadian dalam hidup individu berpengaruh terhadap kondisi stres dan distres individu.

Hipotesis 2: Ada pengaruh langsung yang signifikan stres pekerjaan, stres kelompok kerja, stres keuangan, stres keluarga, dan kepuasan kerja terhadap kinerja 


\section{a. Pengaruh stres pekerjaan te rhadap kinerja karya wan}

Hasil penelitian menyatakan hubungan yang negatif antara stres pekerjaan dengan kinerja karyawan pada Satuan Polisi Pamong Praja. Hasil pengujian hipotesis menyatakan bahwa ada pengaruh yang signifikan antara variabel stres pekerjaan terhadap kinerja karyawan, dapat dibuktikan. Stres pekerjaan yang terdiri dari konflik peran, kemenduaan peran, dan beban kerja yang dirasa oleh karyawan dapat menurunkan kinerja. Hal ini dibuktikan dengan nilai t hitung sebesar 2,156 yang lebih besar dari nilai t tabel 1,980 dengan nilai probabilitasnya yang lebih kecil dari 0,05 yaitu 0,034 .

Hasil penelitian ini sejalan dengan penelitian yang dilakukan Kode Ruyter, Martin Wetzels, dan Richard Feinberg (2001) yang menyatakan terdapat pengaruh yang signifikan tekanan peran terhadap kinerja.

\section{b. Pengaruh stres kelompok kerja terhadap kinerja karyawan}

Hasil penelitian menyatakan hubungan yang negatif antara stres kelompok kerja dengan kinerja karyawan dengan status kontrak pada Satuan Polisi Pamong Praja. Hasil pengujian hipotesis yang menyatakan terdapat pengaruh yang signifikan variabel stres kelompok kerja terhadap kinerja karyawan, tidak dapat dibuktikan. Hal ini dibuktikan dengan nilai t hitung sebesar 1,543 yang lebih kecil dari nilai t tabel sebesar 1,980 dengan nilai probabilitasnya lebih besar dari 0,05 yaitu 0,126 .

Hasil penelitian ini tidak mendukung terhadap temuan oleh Endang Sri Murlijanti (2004) yang menyatakan terdapat pengaruh yang signifikan stres kelompok kerja terhadap kinerja karyawan. 


\section{c. Pengaruh stres keuangan terhadap kinerja karya wan}

Hasil penelitian menyatakan hubungan yang negatif antara stres keuangan dengan kinerja karyawan dengan status kontrak pada Satuan Polisi Pamong Praja. Hasil pengujian hipotesis yang menyatakan terdapat pengaruh yang signifikan variabel stres keuangan terhadap kinerja karyawan, dapat dibuktikan. Hal ini dibuktikan dengan nialai t hitung sebesar 8,281 yang lebih besar dari nilai t tabel sebesar 1,980 dengan nilai probabilitasnya yang lebih kecil dari 0,05 yaitu 0,00.

Hasil penelitian ini mendukung terhadap penelitian yang dilakukan oleh Joo dan Garman (1998) yang menyatakan bahwa karyawan bentuk hubungan stres keuangan dengan ketidakhadiran adalah positif, tingkat baiknya kondisi keuangan berhubungan dengan ketidakhadiran, dan karyawan yang mempunyai pengalaman stres keuangan periode sebelumnya akan melakukan ketidakhadiran.

\section{d. Pengaruh stres keluarga terhadap kinerja karyawan}

Hasil penelitian ini menunjukkan terdapat pengaruh yang signifikan variabel stres keluarga terhadap kinerja dengan bentuk hubungan yang negatif. Hal ini dibuktikan dengan nilai t hitung sebesar 2,462 yang lebih besar dari t tabel sebesar 1,980 dengan nilai probabilitasnya lebih kecil dari 0,05 yaitu 0,016 .

Maramis (1980) menyatakan kondisi keluarga yang kurang harmonis, persoalan anak dan anggota keluarga yang lain yang menjadi tanggungan, seringkali menjadi faktor penyebab perselisihan yang pada akhirnya mengganggu konsentrasi individu dalam malakukan aktivitas.

\section{e. Pengaruh kepuasan kerja terhadap kinerja karyawan}

Hasil penelitian ini menunjukkan terdapat pengaruh yang signifikan variabel kepuasan kerja terhadap kinerja dengan bentuk hubungan yang posistif. Faktor 
kepuasan kerja yang berhubungan dengan pekerjaan itu sendiri, ganjaran, kondisi kerja, dan kesesuaian pekerjaan dengan pribadi dirasakan oleh karyawan Satuan Polisi Pamong Praja dengan status kontrak dapat mempengaruhi kinerja. Hal ini dibuktikan dengan nilai t hitung sebesar 2,916 yang lebih besar dari nilai t tabel sebesar 1,980 dengan nilai probabilitasnya lebih kecil dari 0,05 yaitu 0,004.

Rusbult \& Lowery (1985, dalam Robbins 1997) mengetengahkan tentang respon terhadap kepuasan dan ketidakpuasan kerja yang diungkapkan lewat perilaku meninggalkan organisasi, memperbaiki kondisi berupa saran perbaikan, kesetiaan, dan pengabaian berupa kemangkiran, datang terlambat, dan tingkat kekeliruan yang meningkat. Vecchio (2000) menyatakan bahwa karyawankaryawan yang terpuaskan itu cenderung melibatkan diri dalam pekerjaannya dan selalu ingin lebih produktif.

Hipotesis 3: Ada pengaruh tidak langsung yang signifikan stres pekerjaan, stres keuangan, dan stres keluarga terhadap kinerja melalui kepuasan kerja

\section{a. Pengaruh stres pekerjaan te rhadap kinerja melalui kepuasan kerja}

Hasil pengujian hipotesis yang menyatakan ada pengaruh tidak langsung stres pekerjaan terhadap kinerja melalui kepuasan kerja, dapat dibuktikan. Sebelumnya telah diketahui pula pengaruh langsung stres pekerjaan terhadap kepuasan kerja dan kinerja karyawan dapat dibuktikan. Stres pekerjaan yang berhubungan dengan konflik peran, kemenduaan peran, dan beban kerja karyawan akan mempengaruhi kepuasan kerja karyawan dan selanjutnya akan mempengaruhi kinerja karyawan. Temuan ini mendukung model Ruyter, Wetzels, dan Feinberg (2001) yang menggambarkan pengaruh tekanan peran terhadap kinerja melalui kepuasan kerja. Dalam penelitian ini beban kerja dimasukkan 
sebagai salah satu indikator tekanan pekerjaan (Gibson, 1996) dengan demikian dapat dikatakan temuan penelitian ini selaras dengan dukungan teori.

\section{b. Pengaruh stres kelompok kerja terhadap kinerja melalui kepuasan kerja}

Hasil pengujian hipotesis yang menyatakan ada pengaruh tidak langsung stres kelompok kerja terhadap kinerja melalui kepuasan kerja, tidak terbukti. Sebelumnya telah diketahui pula pengaruh langsung stres kelompok kerja terhadap kepuasan kerja dan kinerja juga tidak dapat dibuktikan. Walaupun tidak terbukti namun arah pengaruhnya negatif. Hal ini mengindikasikan bahwa meski tidak terbukti signifikan akan tetapi masih memiliki pengaruh yang berpotensi menurunkan kepuasan kerja dan kinerja karyawan. Anorogo \& Widiyanti (1990) menyatakan stres yang terjadi pada karyawan merupakan hal yang wajar, akan tetapi apabila hal ini dibiarkan berkelanjutan dan mengarah pada tingkat stres yang tinggi maka nantinya akan berpengaruh negatif pada kinerja karyawan.

\section{c. Pengaruh stres keuangan terhadap kinerja melalui kepuasan kerja}

Hasil pengujian hipotesis yang menyatakan ada pengaruh tidak langsung stres keuangan terhadap kinerja karyawan melalui kepuasan kerja, dapat dibuktikan. Sebelumnya telah diketahui pula stres keuangan berpengaruh langsung terhadap kepuasan kerja dan kinerja karyawan dapat dibuktikan. Stres keuangan yang berhubungan dengan sistem penggajian karyawan akan mempengaruhi kepuasan kerja karyawan dan selanjutnya akan mempengaruhi kinerja dari karyawan. Penelitian ini mendukung model yang dikembangkan oleh Ruyter, Wetzels, dan Feinberg (2001). Dalam penelitian ini variabel stres keuangan ditambahkan sebagai salah satu variabel stres. Williams, Haldeman, dan Cramer (1996) menyatakan bahwa masalah keuangan sangat mempengaruhi 
tingkat produktivitas kerja individual dan hubungan perseorangan. Garma dan Leech (1996) menyatakan pengalaman stres individu yang disebabkan oleh faktor keuangan berakibat terhadap rendahnya produktivitas dan kepuasan kerja. Dengan demikian dapat dikatakan temuan dalam penelitian ini selaras dengan dukungan teori.

\section{d. Pengaruh stres keluarga te rhadap kinerja melalui kepuasan kerja}

Hasil pengujian hipotesis yang menyatakan bahwa ada pengaruh tidak langsung stres keluarga terhadap kinerja melalui kepuasan kerja, dapat dibuktikan. Sebelumnya telah diketahui pula pengaruh stres keluarga terhadap kepuasan kerja dan kinerja dapat dibuktikan. Kejadian penting dalam keluarga, jumlah anggota keluarga yang menjadi tanggungan, dan tugas rumah yang harus dikerjakan sebelum berangkat kerja dapat mempengaruhi kepuasan kerja karyawan dan selanjutnya akan mempengaruhi kinerja dari karyawan. Penelitian ini mendukung model yang dikembangkan Ruyter, Wetzels, dan Freinberg (2001). Dalam penelitian ini variabel stres keluarga digunakan sebagai salah satu variabel stres. Luthans (2002) mengelompokkan keluarga kedalam sumber stres diluar kehidupan organisasi (extraorganizational) yang dapat mempengaruhi perilaku individu baik secara fisiologis (ketidakpuasan kerja) maupun organisatoris (ketidakhadiran).

\section{Implikasi Penelitian}

Hasil penelitian dilapangan menunjukkan bahwa stres pekerjaan, stres keuangan, dan stres keluarga berpengaruh terhadap kepuasan kerja dan kinerja karyawan, sedangkan stres kelompok kerja tidak menunjukkan pengaruh yang 
signifikan terhadap kepuasan kerja dan kinerja karyawan. Pengaruh variabel stres pekerjaan, stres keuangan, dan stres keluarga bersifat negatif. Jadi semakin tinggi stres pekerjaan, stres keuangan, dan stres keluarga akan menurunkan kepuasan kerja dan kinerja karyawan dengan status kontrak pada Satuan Polisi Pamong Praja Kota Batu.

Dalam hal implikasi operasional dari temuan-temuan dalam penelitian ini dapat dikatakan bahwa oraganisasi dituntut mengerti dan mengantisipasi kemungkinan munculnya stres dikalangan karyawan yang dapat mengakibatkan menurunnya kepuasan kerja dan kinerja secara individual. Berdasarkan dari hasil penelitian, hendaknya manajemen Kantor Satuan Polisi Pamong Praja Kota Batu berusaha untuk memperbaiki sistem penggajian dari karyawan dengan status kontrak, mengingat sebagian besar karyawan Kantor Satuan Polisi Pamong Praja adalah dengan status kontrak. Selain itu kejelasan dari tugas, garis perintah, dan pelatihan dalam menghadapi masyarakat dalam kaitannya dengan tugas, hendaknya menjadi perhatian manajemen.

Dalam hal hasil penelitian yang berkaitan dengan stres kelompok kerja yang ditemukan tidak signifikan berpengaruh baik terhadap kepuasan kerja maupun kinerja, manajemen Satuan Polisi Pamong Praja Kota Batu bisa meningkatkan rasa keakraban dan kekeluargaan diantara karyawan dengan status kontrak tersebut.

Hal ini menjadi penting karena jika stres karyawan dibiarkan terjadi dan cenderung meningkat akan menurunkan rasa kepuasan dan kinerja, dan tidak menutup kemungkinan akan menghambat pencapaian tujuan organisasi. Sebagai masukan, manajemen Kantor Satuan Polisi Pamong Praja Kota Batu mulai 
mempertimbangkan untuk membentuk bagian konseling yang menangani secara khusus permasalahan-permasalahan yang berhubungan dengan karyawan.

Selain itu untuk pengembangan di masa datang sesuai dengan temuan penelitian ini yaitu stres keuangan berpengaruh nyata terhadap kepuasan kerja, maka pemberian upah atau gaji yang mengacu kesesuaian dan keadilan hendaknya menjadi perhatian bagi organisasi dalam mengambil keputusan khususnya yang berkaitan dengan karyawan dengan status kontrak.

\section{KESIMPULAN}

1. Dari hasil penelitian pengaruh langsung stres pekerjaan, stres keuangan, dan stres keluarga terhadap kepuasan kerja dapat dibuktikan. Sedang pengaruh stres kelompok kerja terhadap kepuasan kerja tidak dapat dibuktikan. Stres pekerjaan, stres keuangan, dan stres keluarga mempunyai hubungan yang negatif terhadap kepuasan kerja, sehingga peningkatan stres pekerjaan, stres keuangan, dan stres keluarga menyebabkan penurunan pada kepuasan kerja.

2. Hasil penelitian pengaruh langsung stres pekerjaan, stres keuangan, dan stres keluarga terhadap kinerja karyawan dapat dibuktikan. Sedang pengaruh stres kelompok kerja terhadap kinerja karyawan tidak dapat dibuktikan. Stres pekerjaan, stres keuangan, dan stres keluarga mempunyai hubungan yang negatif terhadap kinerja, sehingga peningkatan stres pekerjaan, stres keuangan, dan stres keluarga menyebabkan penurunan pada kinerja karyawan.

3. Pengaruh tidak langsung stres pekerjaan, stres keuangan, dan stres keluarga terhadap kinerja karyawan melalui kepuasan kerja dapat dibuktikan. Sedang 
pengaruh tidak langsung stres kelompok kerja terhadap kinerja karyawan melalui kepuasan kerja tidak dapat dibuktikan. 


\section{DAFTAR PUSTAKA}

Afzalur, R. 1996. Stress, Strain, and Their Moderator: an Empirical Comparison of Enterpreneurs and managers. Journal of Small Business Management. 34 (1):46-58.

Anagoro, P dan N. Widiyanti. 1990. Psikologi dalam Perusahaan. PT. Rineka Cipta. Jakarta.

Athar, Shahid M. D. 2005. Islamic Perspective on Stress Management. http://Islam-USA.com/6.html. Diakses 1 November 2005.

Bailey, William C., D. Kay Woodiel, M. Jean Turner \& Jenifer Young B.S. 1998. The Relationship of Financial Stress to Overall Stress and Satisfaction. Personal Finance and worker Productivity. 2 (2).

Brough, Paula \& Judi Pears. 2004. Evaluating The Influe nce of The Type of Social Support On Jon Satisfaction and Work Related Psychological Wellbeing. International Journal of Organisational Behaviour. 8 (2): 472-485.

Cole, Donald .C., Selahadin I., Harry S., Fran E. S,. and John E. 2002. Work and life stressors and psychological distress in the Canadian working population: A structural equation modelling approach to analysis of the 1994 National Population Health Survey. Journal Occupational Health Psychology. 23 (3).

Davis, Keith. dan John W. Newstrom. 1996. Perilaku Dalam Organisasi. Jilid II. Edisi ketujuh. Alih Bahasa Agus Dharma, Sh, M.Ed. Penerbit Erlangga. Jakarta

Dwyer, Dale. J. \& Marilyn L. Fox. 2001. The Relationship Among Work Stressor and Key Performance Indicators: A Test of the Moderating Effects of Control and Customer Service Training in Call Centers. http://www.google.com. Diakses 7 Oktober 2005.

Fletcher, B. 1991. Work, Stress, Disease and Life Expectancy. John Wiley and Sons Ltd. Chichester.

Gibson, James, John Ivancevich dan James Donelly Jr. 1996. Organisasi, Perilaku, Struktur dan Proses. Jilid I. Edisi kedelapan. Alih Bahasa Ir. Nunuk Adiarni, MM. Penerbit Binarupa Aksara. Jakarta.

Gitosudarmo, I. dan I Nyoman Sudita. 1997. Perilaku Keorganisasian. BPFE. Yogyakarta.

Gujarati, Damodar.1993. Ekonometrika Dasar. Penerbit Erlangga. Jakarta. 
Indriantoro, Nur. \& Bambang Supomo. 1999. Metodologi Penelitian Bisnis. BPFE. Yogyakarta.

Joo, So-hyun \& E. Thomas Garman. 1998. Personal Financial Wellness May be the Missing Factor in Understanding and Reducing Worker Absesteeism. Personal Finance and Worker Productivity. 2 (2).

Lazarus, R.S., and Folkman. 1986. Cognitive Theories of Stress and the Issue of Circularity of Stress Psychological. Plenum Press. New York.

Luthans, F. 1995. Organizational Behavior. Ninth edition. McGraw-Hill. Singapore.

Mackie, S Kathleen., Carole K. Holahan, Nell H. Gottlieb. 2001. Employee Involvement Management Practice, Work Stress, and Depression in Employees of Human Service Residential Care Facility. Journal of Human Resources Management. 54 (8)

Malayu, 2000. Manajemen Sumber Daya Manusia, Bumi Aksara, Bandung.

Maramis, W.F. 1980. Ilmu Kedokteran Jiwa. Cetakan keenam. Airlangga University Press. Surabaya.

Martinez, Cheryl. 2004. Job Stress And Satisfaction In Child Welfare: An Analysis of The Impact of Group Supervision. The Manitoba Journal of Child Welfare. 3 (2) Oktober.

Miner, J.B. 1998. Human Behaviour in Organization: The Level of Analysis. Englewood cliffs. New Jersey.

Robbins, Stephen. 2001. Organizational Behavior. San Diego State University Prentice Hall International, Inc.

Ruyter, K., Martin Wetzels \& Richard Feinberg. 2001. Role Stress In Call Centers: Its effect On Employee Performance and Satisfaction. Journal of Interactive Marketing. 15 (2).

Santoso, Singgih .2000. Buku Latihan SPSS Statistik Parametik. Penerbit Elex Media Komputindo. Jakarta

Singarimbum, Masri dan Sofian Effendi. 1995. Metode Penelitian Survei. LP3ES. Jakarta.

Steers, R.M. and Porte. 1987. Introduction to Organizational Behavior. $2^{\text {nd }}$ ed. Scott Foresman and Company. Glenview, Illionis. 
Um, Myung-Yong \& Dianne F. Harrison. 1998. Role Stressor, Burnout, Mediators, and job Satisfaction: A Stress-Strain-Outcome Model and an Empirical test. Social Work Research. 22 (2): 100.

* M. Fatkhur Rozi, SE., MM, Dosen Fakultas Ekonomi UIN Malang. 